\title{
A review of soil degradation in the Philippines
}

\author{
Victor B. Asio ${ }^{1}$, Reinhold Jahnn ${ }^{2}$, Federico 0. Perez ${ }^{3}$, lan A. Navarrete ${ }^{4}$ \\ and Sergio M. Abit Jr. ${ }^{1}$ \\ ${ }^{1}$ Department of Agronomy and Soil Science, Visayas State University, \\ Baybay City, Leyte 6521-A, Philippines. \\ ${ }^{2}$ Soil Science and Soil Protection Division, Institute of Agricultural and Nutritional \\ Sciences, Martin Luther University Halle-Wittenberg, \\ Weidenplan 14, 06108 Halle, Germany. \\ ${ }^{3}$ College of Agriculture, Central Luzon State University, \\ Munoz, Nueva Ecija, Philippines. \\ ${ }^{4}$ United Graduate School of Agricultural Sciences, Iwate University, \\ Iwate 020-8550, Japan.
}

\begin{abstract}
The paper reviews the available information on soil degradation which is a major agricultural and environmental problem in the Philippines. Soil erosion appears to be the most widespread process of soil degradation and is also the most studied. Other important but less studied soil degradation processes include loss of nutrients and organic matter, salinization, acidification, pollution, compaction, and subsidence. Studies reviewed have shown that the widespread degraded upland soils possess chemical and physical constraints for crop growth like acidic or calcareous chemical condition, low organic matter and nutrient contents, shallow solum, presence of toxic substances and compaction. There is a need for more data on the physical and socio-economic characteristics of degraded lands to aid in the formulation of appropriate soil management strategies to support biodiesel production in these unproductive lands which is now being promoted by the Philippine government.
\end{abstract}

Key words: Degraded uplands, land use change, soil degradation, soil erosion, tropical soils

Correspondence: V. B. Asio Address: Department of Agronomy and Soil Science, Visayas State University, Baybay City, Leyte 6521-A, Philippines. Telephone: (053)335-2627 E-mail: vbasio_ph@yahoo.com.

Dol: $10.32945 /$ atr3124.2009 


\section{INTRODUCTION}

Soil is a vital resource for human survival in that it is the medium in which most plants grow, it cleans and stores water, detoxifies pollutants, and plays a key role in the regulation of the Earth's temperature. Soil is also the habitat of a multitude of soil organisms necessary for the cycling of elements and for keeping a healthy environment for human beings (Blum, 2007). Also, many of the important antibiotics to treat human diseases are products of soil bacteria. Worldwide, soil resources are degraded at an unprecedented rate due to various human activities.

Soil degradation is a severe global problem of modern times (Lal, 1998). Steiner (1996) noted that every year 5 to 7 million hectares of agricultural land worldwide become unproductive due to physical and chemical degradation. The problem is much more serious in tropical than in temperate areas since tropical soils are more prone to degradation because of their properties and the prevalent climatic conditions. Countries or sub-regions in Asia and Africa that depend upon agriculture as the engine of economic growth will probably suffer the most (Scherr, 1999). In the Philippines, the National Action Plan (NAP) for 2004 to 2010 identified soil degradation as a major threat to food security. It reported that about 5.2 million hectares are seriously degraded resulting to 30 to $50 \%$ reduction in soil productivity and water retention capacity (NAP, 2004). Because of this, NAP identifies the control of soil degradation as one of the major research priorities for the Philippines. Atienza et al. (2008) reported that there is a need for a coordinated and continual appraisal and protection of soil resources in the Philippines.

The objective of this paper is to review the available information on the processes and management of soil degradation in the Philippines.

\section{The nature of soil degradation}

Soil degradation is defined as the process which lowers the current or future capacity of the soil to produce goods or services. It implies long-term decline in soil productivity and its environment-moderating capacity (Blum, 1998; Lal, 2001). According to Stremme (1930) the concept of soil degradation was first used by Kostychiev and Korchinski 
in 1888 to describe a natural soil change. Since natural degradation is slow, the present concept of soil degradation according to the Global Assessment of Soil Degradation (GLASOD) focuses on a human-induced process (UNEP, 1992). Soil degradation occurs because of drastic changes or disruption in the normal processes of soil formation due to human activities. Blum (1998) considers soil degradation as a loss or reduction in soil energy. While soil formation results in ordering of the soil body and thus decreases entropy (Smeck et al., 1983), soil degradation due to erosion, destruction of soil structure, leaching and decomposition and other processes results in an increase in disorder of the soil body or entropy (Addiscott, 1995). When this happens, the capacity of the soil to function as medium for plant growth, habitat of soil flora and fauna, and as ecological buffer and filter is greatly diminished (Blum, 1998).

The GLASOD recognized two categories of soil degradation (Oldeman, 1994). The first category is soil degradation due to displacement of soil material such as soil erosion by wind and water. The second category is in situ soil degradation due to chemical processes like loss of nutrients and organic matter, salinization, acidification, and pollution and due to physical processes such as compaction, waterlogging and subsidence (Oldeman, 1994). In their assessment of soil degradation in South and Southeast Asia, Van Lynden and Oldeman (1997) found that water erosion, chemical degradation and physical degradation are the major soil degradation processes in the region. They reported that water erosion is largely caused by agricultural practices particularly overgrazing and by deforestation; chemical degradation is almost exclusively the result of improper management of cultivated arable lands; and physical degradation is largely due to agricultural activities. The major factors that cause soil degradation include deforestation, overgrazing, agricultural practices, industrial activities, mining, and waste disposal. Deforestation is the main cause of soil degradation in Asia and South America while overgrazing is the main factor in the dryland areas of Australia, Africa, Europe and Asia (UNEP, 1992). In the Philippines, Cramb et al. (2000) observed the important role of rapid population growth and widespread rural poverty that induce lowland farmers to migrate into steeply sloping upland areas where their cultivation technique are inappropriate and causes accelerated erosion. 


\section{Soil degradation processes in the Philippines}

\section{Soil erosion}

Soil erosion removes the usually fertile topsoil resulting in the reduction of the productive capacity of the soil. In many upland areas throughout the country, the reddish appearance of the soil is due to the exposure of humus-poor but iron oxide-rich subsoils after the dark and humus-rich topsoils have been removed by erosion (Asio, 1997). The natural factors affecting soil erosion by water include rainfall, vegetative cover, the slope of the land, and soil erodibility (Lal, 1984; Presbitero 2003). The Philippines has a wet tropical climate with an annual rainfall ranging from about $1,000 \mathrm{~mm}$ in the south to more than $4,000 \mathrm{~mm}$ in mountainous areas particularly along the eastern coast of the archipelago. This is aggravated by the occurrence of an average of 15-20 typhoons per year (PCARRD, 2009). About 60 percent of the country has rugged and mountainous topography with large areas in some islands having more than 18 percent slope (Fig. 1). Deforestation and land use change have reduced the forest cover in the Philippines from about 90 percent in the middle of the 16th century, to 70 percent by 1900 and about 23 percent by 1987 (Garrity et al., 1993; Verburg \& Veldkamp, 2004). Some islands like Cebu and Bohol have even zero original forest cover. Soils in most sloping lands are either poorly developed and unstable or heavy clay with low infiltration capacity both of which favor soil loss.

Until now, no comprehensive nationwide assessment of soil erosion has yet been done in the Philippines. Because of this, estimates of the severity of the erosion problem greatly vary. The NAP (2004) estimated that 33, 21 and 46 percent of Luzon, Visayas and Mindanao, respectively, are severely eroded. The data for the Visayas clearly appear as an underestimation considering the degraded nature of many Visayas islands. For example, for Leyte island alone, the Bureau of Soil and Water Management (BSWM, 1992) reported that about 40 percent of the soils in northern Leyte and about 58\% in Southern Leyte are moderately to severely eroded (Table 1). Another agency report estimated that about 53 percent of the 8 million hectares of agricultural land have been degraded by erosion while on a national scale, 63 percent of the total land area is 


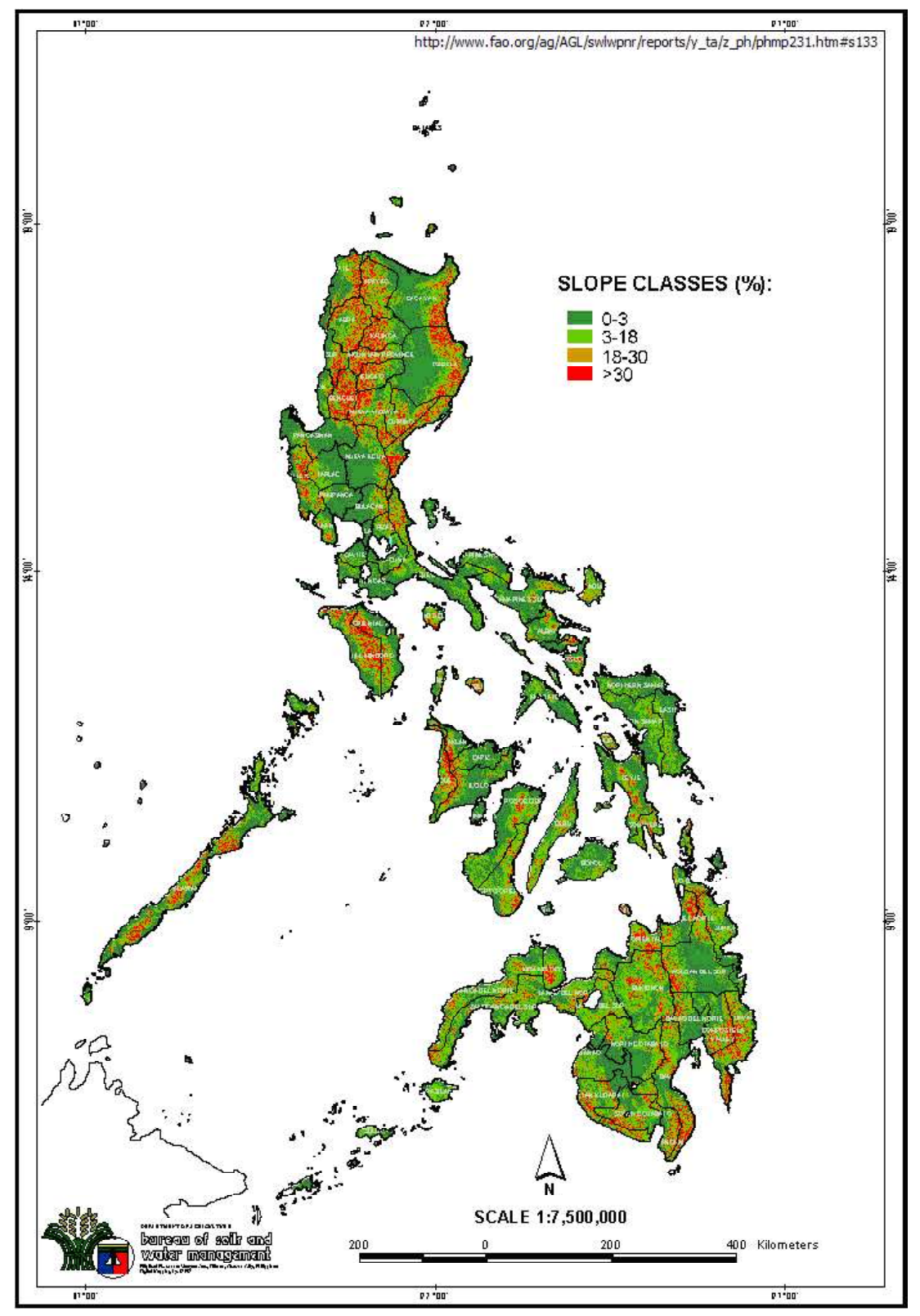

Fig.1. Slope classes in the Philippines 
Table 1. Extent of soil erosion problem in Leyte, Philippines (in percent)

\begin{tabular}{lccc}
\hline Degree of soil erosion & Northern Leyte & Southern Leyte & Average \\
\hline E0- No apparent erosion & 36.6 & 15.6 & 26.1 \\
E1- Slight erosion & 21.8 & 24.1 & 22.9 \\
E2- Moderate erosion & 19.3 & 25.7 & 22.5 \\
E3- Severe erosion & 19.9 & 32.3 & 26.1 \\
E4- Unclassified erosion & 2.4 & 2.3 & 2.3 \\
\hline
\end{tabular}

Source: BSWM (1992)

eroded (PCARRD, 1992). David (1988) noted that one third of the total land area of the Philippines has been excessively eroded. In terms of erosion rates, estimates vary considerably with land use systems and across different areas in the country (Table 2). The highest reported erosion rate was measured in a banana-coffee-pineapple intercropping (421 $\mathrm{t} \mathrm{ha}^{-1} \mathrm{yr}^{-}$ $\left.{ }^{1}\right)$ and the lowest erosion rate was recorded under a primary forest $(0.2 \mathrm{t}$ $\left.\mathrm{ha}^{-1} \mathrm{yr}^{-1}\right)$. These values are comparable to those reported by The World Bank (1989) showing rates of soil loss ranging from $1 \mathrm{t} \mathrm{ha}^{-1} \mathrm{yr}^{-1}$ under undisturbed forest to around 300-400 $\mathrm{tha}^{-1} \mathrm{yr}^{-1}$ on kaingin (slash and burn) or shifting cultivation plots. In Leyte, Siebert (1987) reported an average of $489 \mathrm{t} \mathrm{ha}^{-1}$ in just 6 months for hillside farms under cultivation while Asio (1996) observed soil erosion rates ranging from $1 \mathrm{t} \mathrm{ha}^{-1} \mathrm{yr}^{-1}$ in natural forest to $23 \mathrm{tha}^{-1} \mathrm{yr}^{-1}$ under coconut and $100 \mathrm{t} \mathrm{ha}^{-1} \mathrm{yr}^{-1}$ in shifting cultivation farms. Comparing the average rates among the 13 regions of the country, it shows an average erosion rate ranging from $56.41 \mathrm{t} \mathrm{ha}^{-1} \mathrm{yr}^{-1}$ in Region I to $128.5 \mathrm{t} \mathrm{ha}^{-1} \mathrm{yr}^{-1}$ in Region II, both located in Luzon (Fig. 2). FAO (1998) reported that the average erosion rate for the entire country is estimated to be $81 \mathrm{t} \mathrm{ha}^{-1} \mathrm{yr}^{-1}$, although this value might be an underestimation of the real soil erosion rate.

Soil erosion also causes offsite effects such as sedimentation of lakes, reservoirs and irrigation canals, and paddy fields. Lantican et al. (2003) noted that as a result of silted canals and ditches, productivity of downstream irrigated lowlands becomes low. They also found that rice yields in farms heavily affected by siltation decreased by $27 \%$ in a period of 5 years. 


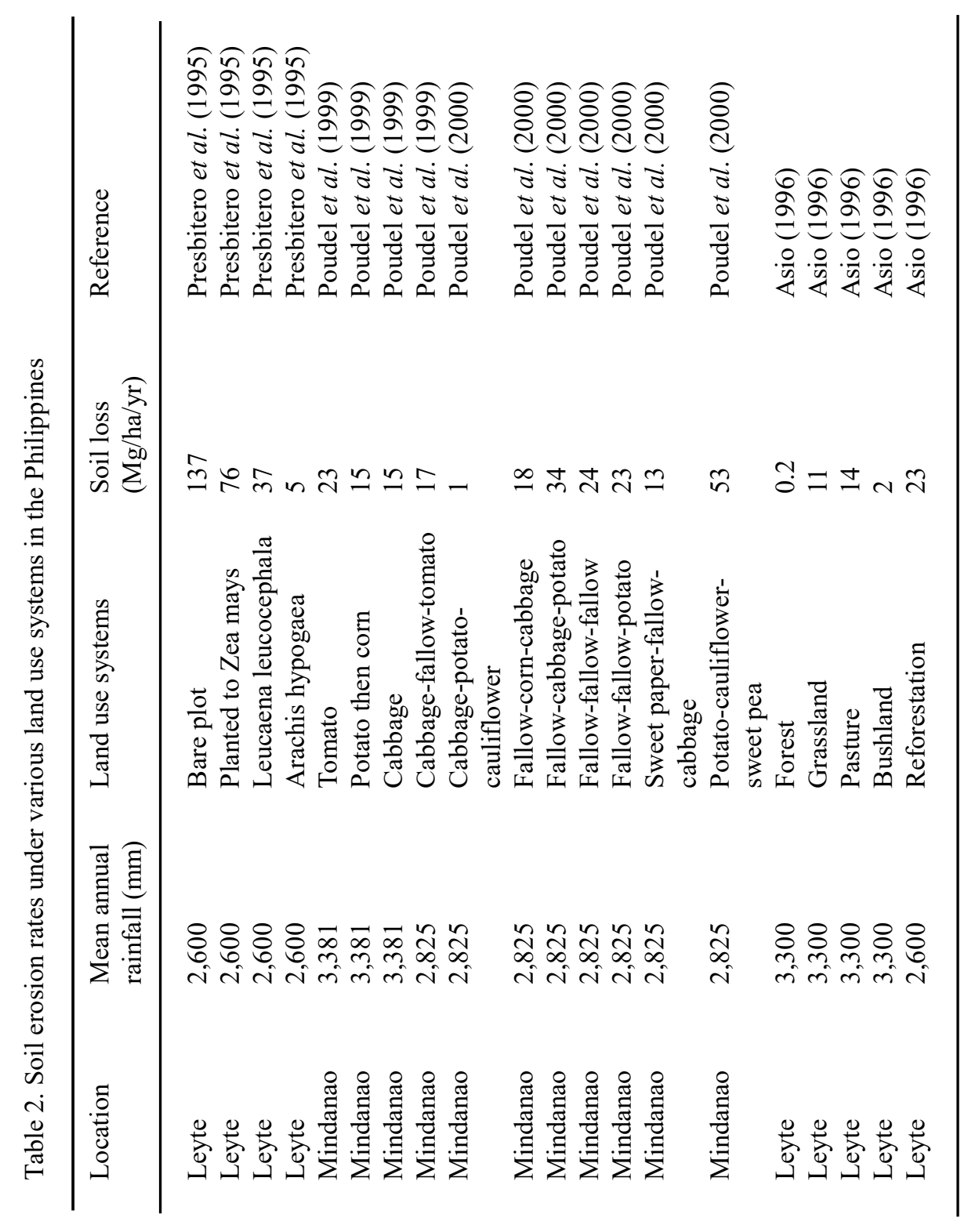




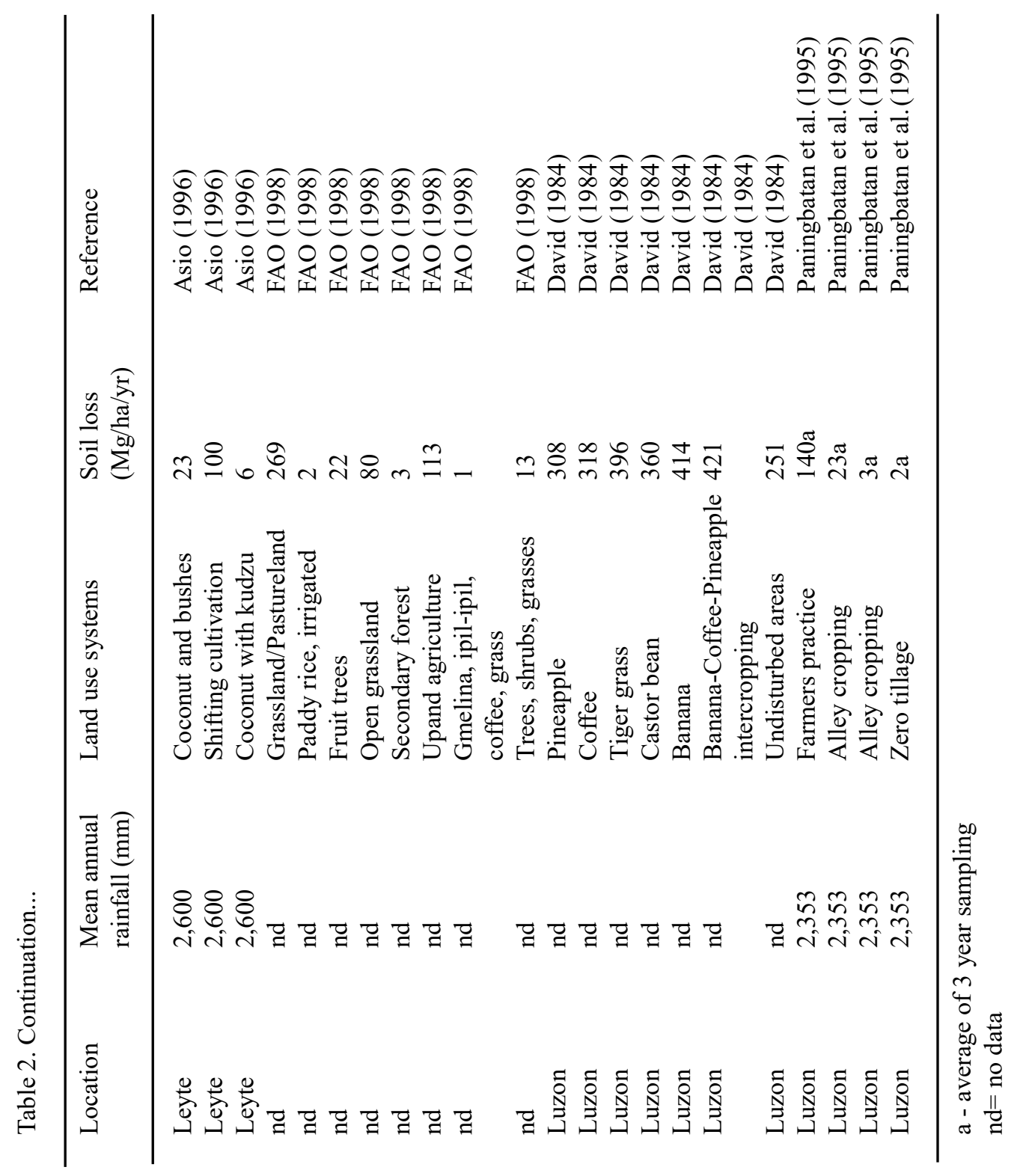




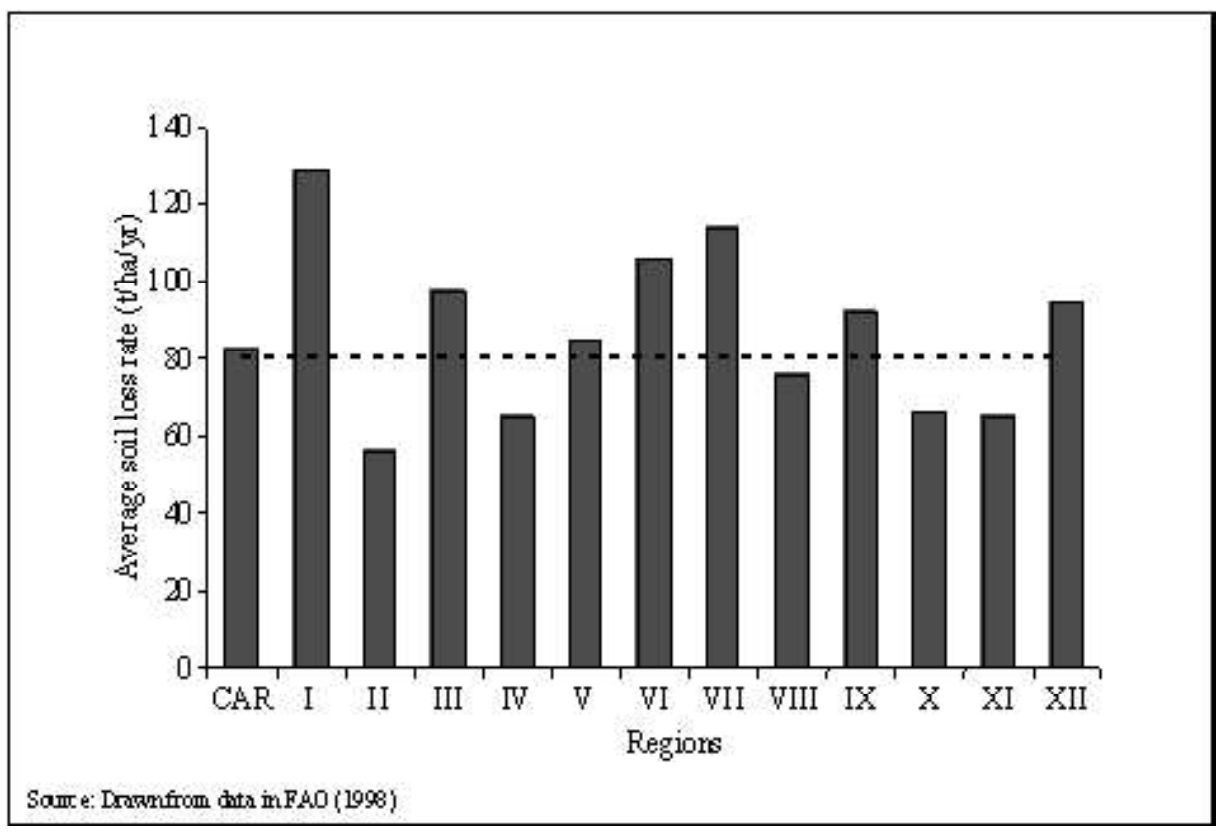

Fig. 2. Average erosion rate by region in the Philippines in 1993. Dotted line represents the average erosion rate

\section{Loss of nutrients and organic matter}

About 70 percent of soils of the Philippines belong to Ultisols (Evangelista, 1993) and unclassified mountain soils which have generally low contents of essential plant nutrients particularly $\mathrm{N}$ and P. Farmers practices that result in loss of nutrients and soil organic matter hasten the degradation of these inherently less fertile soils. The loss of essential nutrients can be due to soil erosion, leaching and removal by the growing plant while for soil organic matter, erosion and decomposition are the major processes of loss. Soil organic matter plays a major role in the productivity of strongly weathered tropical soils because it represents the dominant reservoir and source of plant nutrients. It also influences $\mathrm{pH}$, cation and anion exchange capacity, and structure of the soil (Sanchez, 1976). In the Philippines, loss of nutrient and organic matter is commonly observed in areas where low-input agriculture is practiced like in most 
Table 3. Effects of forest conversion to secondary land uses on topsoil organic matter content

\begin{tabular}{lc} 
Land use & Organic Matter (\%) \\
\hline Ormoc site (Andisol) & 14.2 \\
Forest & 6.9 \\
Grassland & 11.6 \\
Pasture & 11 \\
Bushland & \\
Baybay site (Ultisol) & 7 \\
Forest & 3.2 \\
Reforestation & 4.1 \\
Coconut and bushes & 3.8 \\
Shifting cultivation & 5.3 \\
Coconut and kudzu & \\
\hline
\end{tabular}

Source: Asio (1996)

upland areas in the country where the soils are of low fertility and where farmers do not practice fertilization. According to FAO (1998) the undiscounted value of soil nutrient loss from the upland fields through soil erosion was estimated to be 5.94 billion pesos (125 million US\$) representing 4.27 percent of the Gross Value Added in agriculture in the Philippines. Siebert (1987) noted that continuous cultivation of corn and sweet potato in a mountain in Leyte gradually exhausted soil calcium, magnesium, available phosphorus and organic matter levels and increased soil acidity. Tables 3 and 4 show an example of the decrease in soil organic matter and humic substances and sugars, respectively, when forest is converted to agriculture and other secondary land uses. The data suggest that soil degradation resulting from forest conversion is accompanied by a decrease in quantity and quality of organic substances and non-cellulosic sugars in the soil. The decrease in humic substances has vital ecological implication in that they are a major component of soil organic matter and account for a large pool of recalcitrant carbon in terrestrial environment (Navarrete \& Tsutsuki, 2008; Navarrete et al., 2008).

\section{Acidification}

The process of soil acidification can be natural (a slow process due to soil formation) or can be caused by human activities. Under conditions 
Table 4. Changes in the organic matter and neutral sugars content of soils due to forest conversion to other land uses in Leyte, Philippines

\begin{tabular}{|c|c|c|c|c|c|c|c|}
\hline & $\begin{array}{l}\text { Depth } \\
(\mathrm{cm})\end{array}$ & $\underline{\text { Corg }}$ & $\frac{\mathrm{HA}}{{\left.\mathrm{g} \mathrm{kg}^{-1}\right)}^{-}}$ & FA & $\begin{array}{l}\text { Total } \\
\text { NC }\end{array}$ & $\begin{array}{l}\text { Total } \\
\text { Cel. }\end{array}$ & $\begin{array}{l}\text { Carbohydrate-C } \\
\text { in total C } \\
\left(\mathrm{g} \mathrm{C} \mathrm{kg} \mathrm{C}^{-1}\right)\end{array}$ \\
\hline $\begin{array}{l}\text { Site } \\
\text { Secondary } \\
\text { forest } \\
\text { (SF) }\end{array}$ & $\begin{array}{l}0-20 \\
20-40 \\
40-60\end{array}$ & $\begin{array}{l}23.5 \\
13.5 \\
12.4\end{array}$ & $\begin{array}{l}0.71 \\
0.18 \\
0.13\end{array}$ & $\begin{array}{l}5.28 \\
3.15 \\
2.75\end{array}$ & $\begin{array}{l}57.3 \\
32.8 \\
22.4\end{array}$ & $\begin{array}{l}24.5 \\
14.2 \\
11.8\end{array}$ & $\begin{array}{l}81.8 \\
47.0 \\
34.2\end{array}$ \\
\hline $\begin{array}{l}\text { Mahogany } \\
\text { plantation } \\
\text { (MP) }\end{array}$ & $\begin{array}{l}0-20 \\
20-40 \\
40-60\end{array}$ & $\begin{array}{l}22.1 \\
11.6 \\
9.0\end{array}$ & $\begin{array}{l}0.73 \\
0.26 \\
0.12\end{array}$ & $\begin{array}{l}3.13 \\
2.09 \\
1.73\end{array}$ & $\begin{array}{l}39.6 \\
18.6 \\
25.9\end{array}$ & $\begin{array}{l}16.4 \\
14.7 \\
17.0\end{array}$ & $\begin{array}{l}56.0 \\
33.3 \\
42.8\end{array}$ \\
\hline $\begin{array}{l}\text { Rainforestation } \\
\text { farming (RF) }\end{array}$ & $\begin{array}{l}0-20 \\
20-40 \\
40-60\end{array}$ & $\begin{array}{l}16.3 \\
10.9 \\
8.9\end{array}$ & $\begin{array}{l}0.63 \\
0.23 \\
0.11\end{array}$ & $\begin{array}{l}3.41 \\
2.12 \\
1.60\end{array}$ & $\begin{array}{l}5.8 \\
6.7 \\
9.5\end{array}$ & $\begin{array}{l}13.6 \\
28.0 \\
20.0\end{array}$ & $\begin{array}{l}19.4 \\
34.6 \\
29.5\end{array}$ \\
\hline $\begin{array}{l}\text { Coffee plantation } \\
\text { (CP) }\end{array}$ & $\begin{array}{l}0-20 \\
20-40 \\
40-60\end{array}$ & $\begin{array}{l}21.5 \\
16.8 \\
15.0\end{array}$ & $\begin{array}{l}0.87 \\
0.38 \\
0.13\end{array}$ & $\begin{array}{l}4.38 \\
2.56 \\
2.19\end{array}$ & $\begin{array}{l}26.7 \\
22.7 \\
16.4\end{array}$ & $\begin{array}{l}22.8 \\
19.3 \\
18.1\end{array}$ & $\begin{array}{l}49.4 \\
42.0 \\
34.5\end{array}$ \\
\hline Grassland (GR) & $\begin{array}{l}0-20 \\
20-40 \\
40-60\end{array}$ & $\begin{array}{l}13.5 \\
11.8 \\
11.9\end{array}$ & $\begin{array}{l}0.37 \\
0.22 \\
0.10\end{array}$ & $\begin{array}{l}2.40 \\
3.34 \\
2.02\end{array}$ & $\begin{array}{l}14.6 \\
11.3 \\
13.8\end{array}$ & $\begin{array}{l}23.4 \\
25.1 \\
15.6\end{array}$ & $\begin{array}{l}38.0 \\
36.4 \\
29.3\end{array}$ \\
\hline
\end{tabular}

Source: Navarrete and Tsutsuki (2008)

$\mathrm{HA}=$ Humic acid; $\mathrm{FA}=$ fulvic acid; Total $\mathrm{NC}=$ total non-cellulosic sugar;

Total Cel. $=$ total cellulosic sugar 
of good drainage and sufficient rainfall to produce leaching, $\mathrm{H} 2 \mathrm{CO} 3$ and soluble organic acids can cause the very slow acidification (Bloom, 2000). Intensive cultivation of upland areas in the Philippines without addition of nutrients and organic matter to the soil is considered to be a contributor to the widespread occurrence of acid upland soils (NAP, 2004) which comprise about half of the upland soils of the Philippines (Evangelista, 1993). Another type of soil acidification can be observed in coastal areas in various parts of the country where mangroves have been converted into rice fields or fishponds. This is because soils in these ecosystems are rich in pyrite $\left(\mathrm{FeS}_{2}\right)$ which when exposed to the air upon drainage, produce sulfuric acid which make the soil extremely acidic ( $\mathrm{pH}$ below 4.0). Such soils are called acid sulfate soils.

\section{Salinization}

This process can be observed in low-lying coastal areas of the country due to salt water intrusion and the use of saline water to irrigate agricultural fields. Philrice (2001) reported that salinity has become a widespread constraint to rice production in most parts of the country. Salinizationprone coastal lands are estimated at $0.4 \mathrm{M}$ ha of which $0.2 \mathrm{M}$ ha is considered severely salt-affected. Places with considerable saline areas are Cagayan valley, Bicol, Iloilo, Palawan, Negros, Samar, Leyte and Surigao. Table 5 shows some characteristics of some coastal saline soils in the Philippines with some growth-limiting factors for rice growth (Ponnamperuma \& Bandyopadya, 1980). Over extraction of ground water in coastal areas for household and agriculture uses is also expected to increase the areas affected by salinization. Rising sea level due to global warming will also increase the problem of sea water intrusion in lowlying coastal areas throughout the country.

\section{Pollution}

Many soils around the country are degraded due to the accumulation of various types of wastes and toxic materials from the industry, mining, households and agricultural activities. Because of the fact that the country is rich in mineral resources, mining has probably caused more extensive 
and severe soil pollution than manufacturing activities. The Mines and Geosciences Bureau (2004) estimated that 30 percent or about 9 million hectares of the total land area of the country have potential for mining of metallic minerals. As of 2004, the number of mining rights issued by the government totaled 632 covering an area of nearly half a million hectares. This is expected to increase in the near future considering the fact that the government has embarked on a program to revitalize the mining industry (Mines and Geosciences Bureau, 2004). The Bagacay Mine in the island of Samar is a classic example of how open pit mining has physically destroyed the forest landscape and polluted the soil and nearby surface waters with heavy metals. The Mines and Geosciences BureauMining Environment and Safety Division (2006) and Edralin (2008) reported extremely high levels of heavy metal in soil in various portions of the abandoned mine as well as in the transported sediments in the lowland. Another example is the case of the Marcopper mining disaster in Marinduque. In March 1996 an estimated 1.5 million cubic meters of mine tailings were disgorged into the Makulapnit and Boac rivers causing flash floods in the downstream area particularly along the western coast of the island (David, 2002). David (2002) noted an elevated concentration of metal $\mathrm{Cu}, \mathrm{Mn}, \mathrm{Pb}$, and $\mathrm{Zn}$ in the offshore sediments, which can be considered as potential source of environmental pollution for marine environment. He further observed the persistence of contamination in the surface sediments even several years after the spill. Although no detailed soil heavy metal study has yet been done, it is expected that the area affected by the flash flood will contain high amounts of heavy metals. In another study, elevated levels of $\mathrm{Pb}$ have been found in soils of 5 urbanized areas in central Luzon (Ona et al., 2006). The study found that an elevated concentration of greater than $25 \mathrm{mg} \mathrm{kg}^{-1} \mathrm{~Pb}$ largely came from the combustion of fossil fuel from vehicles.

\section{Compaction and waterlogging}

Soil compaction is primarily caused by the long-term use of heavy farm equipment and by overgrazing. Van Lynden and Oldeman (1997) estimated that soil compaction affects 1.4 million hectares of land in the 


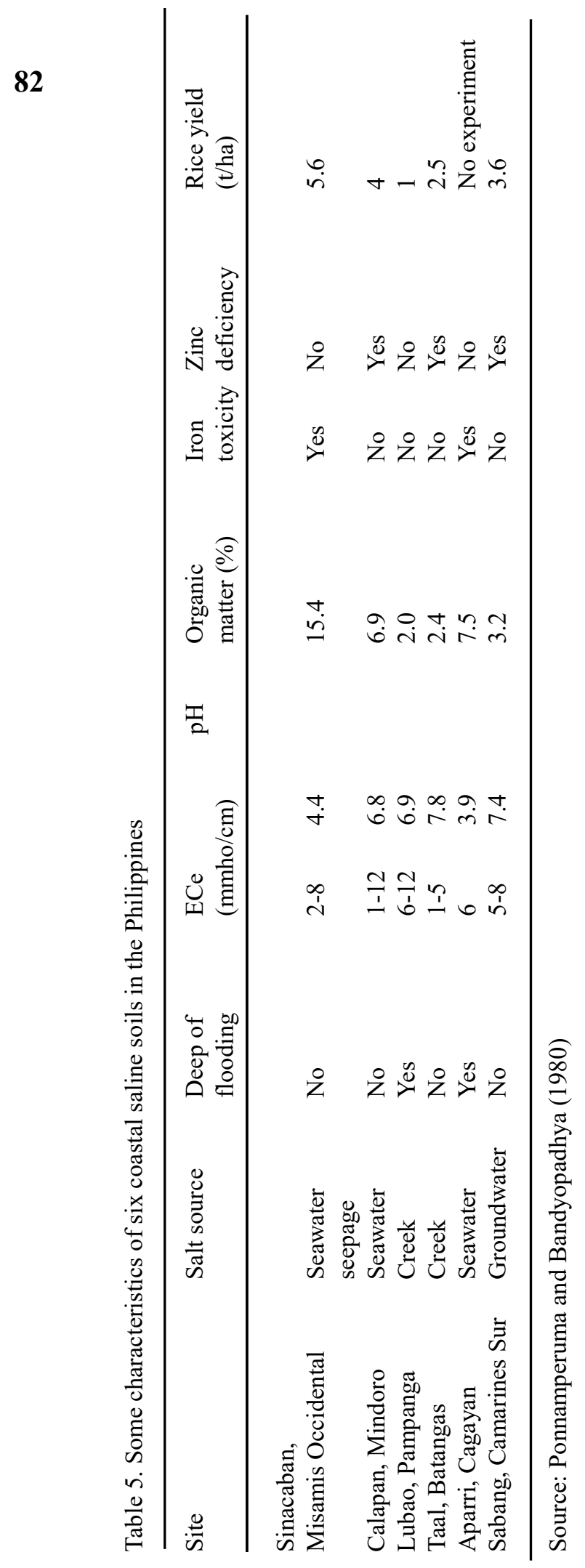

Asio et al. 
Philippines. Low organic matter content of the soil (i.e. $<2$ percent) contributes to soil compaction that can lead to the unfavorable growth of crops. Navarrete et al. (2000) found very high soil strength (in $\mathrm{kg}$ force $\mathrm{cm}^{-2}$ ) in the upper $30 \mathrm{~cm}$ of a degraded upland soil in Pinabacdao Samar reflecting the highly compacted nature of the top soil which was also revealed by high bulk density values. Although very little is available on the occurrence of soil compaction in cultivated areas around the country, it is nonetheless believed to be an important factor limiting crop production especially in intensively cultivated lands like in large plantations in Mindanao. Waterlogging occurs in areas where the natural drainage has been altered by human activities especially for lowland rice production. Although there is some degree of degradation of the physical properties of the soil when it is subjected to prolonged lowland rice cultivation, most young alluvial soils in the Philippines appear able to recover once they are drained again and used for upland crop production.

\section{Fertility of degraded upland soils}

Soil fertility is the capacity of the soil to supply nutrients to the plants in proper amounts and proportions. It greatly determines agricultural production especially in upland environments where subsistence farmers do not have the means to buy the expensive fertilizers. For better understanding of the fertility of degraded upland soils which are the most widespread in the Philippines, Leyte island in the Visayas is used as example since more recent research on soil degradation has been done on that island.

Table 6 and 7 present the site characteristics and chemical data for the topsoil, respectively, of 20 degraded upland soils in various parts of Leyte. The soils were derived from various parent materials such as mixed and volcanic sediments, volcanic rocks and ophiolite complex rocks. They also greatly vary in land use as well as topography implying that the soils have different soil genesis and soil degradation processes.

Based on soil fertility indicators like soil $\mathrm{pH}, \mathrm{OM}$ and nutrient contents, the degraded soils have low fertility status. Soil $\mathrm{pH}$ values range from 4.1 to 5.6 with an average of 5.0 indicating very strongly acidic condition. OM contents range from 1.43 percent (very low) to 
Table 6. Site characteristics of degraded upland soils in Leyte, Philippines

\begin{tabular}{lllll}
\hline Soil & Location & Geology & Land Use & Topography \\
\hline 1 & Babatngon & ophiolite complex & bushland & undulating to hilly \\
2 & Tacloban & ophiolite complex & bushland & undulating to hilly \\
3 & Capoocan & intermediate volcanics & cropland & mountainous \\
4 & Capoocan & intermediate volcanics & grassland & mountainous \\
5 & Kananga & volcanic sediments & cropland & rolling to undulating \\
6 & Kananga & volcanic sediments & cropland & rolling to undulating \\
7 & Ormoc & volcanic sediments & grassland & rolling to undulating \\
8 & Baybay & intermediate volcanics & forest & hilly to steeply sloping \\
9 & Baybay & intermediate volcanics & bushland & hilly to steeply sloping \\
10 & Baybay & intermediate volcanics & cropland & hilly to steeply sloping \\
11 & Baybay & intermediate volcanics & forest & hilly to steeply sloping \\
12 & Mahaplag & intermediate volcanics & bushland & mountainous \\
13 & Mahaplag & intermediate volcanics & cropland & mountainous \\
14 & Mahaplag & intermediate volcanics & bushland & mountainous \\
15 & Inopacan & mixed sediments & bushland & rolling to undulating \\
16 & Bato & mixed sediments & cropland & rolling to undulating \\
17 & Matalom & mixed sediments & grassland & rolling to undulating \\
18 & Sogod & intermediate volcanics & cropland & mountainous \\
19 & Hinunangan & mixed sediments & bushland & mountainous \\
20 & St Bernard & intermediate volcanics & bushland & hilly to steeply sloping \\
\hline & m & & &
\end{tabular}

Source: Asio (2007)

5.17 percent (medium) with an average of 3.5 (low), while total $\mathrm{N}$ contents have an average value of 0.16 percent (low). These values reflect the direct effect of the land use and other human activities. All the soils have low $\mathrm{P}$ availability (average of $2 \mathrm{mg} \mathrm{kg}^{-1}$ ) which is below the favorable amount Landon (1991) of 8 to $15 \mathrm{mg} \mathrm{kg}^{-1}$ indicating that $\mathrm{P}$ is a major limiting nutrient to crop production in degraded upland soils (Siebert, 1987; Asio et al., 1998; Navarrete et al., 2007). This can be attributed to the generally low $\mathrm{P}$ content of the parent rocks and to the strongly acidic or alkaline chemical condition of the soils. In soils derived from volcanic ash particularly Andisols in different parts of the country, the presence of non-crystalline clay minerals such as allophane and imogolite have also resulted to $P$ fixation in the soil (Asio, 1996). Most of the soils have exchangeable $\mathrm{K}$ contents above the critical value of $0.2 \mathrm{cmol} \mathrm{kg}^{-1}$ 


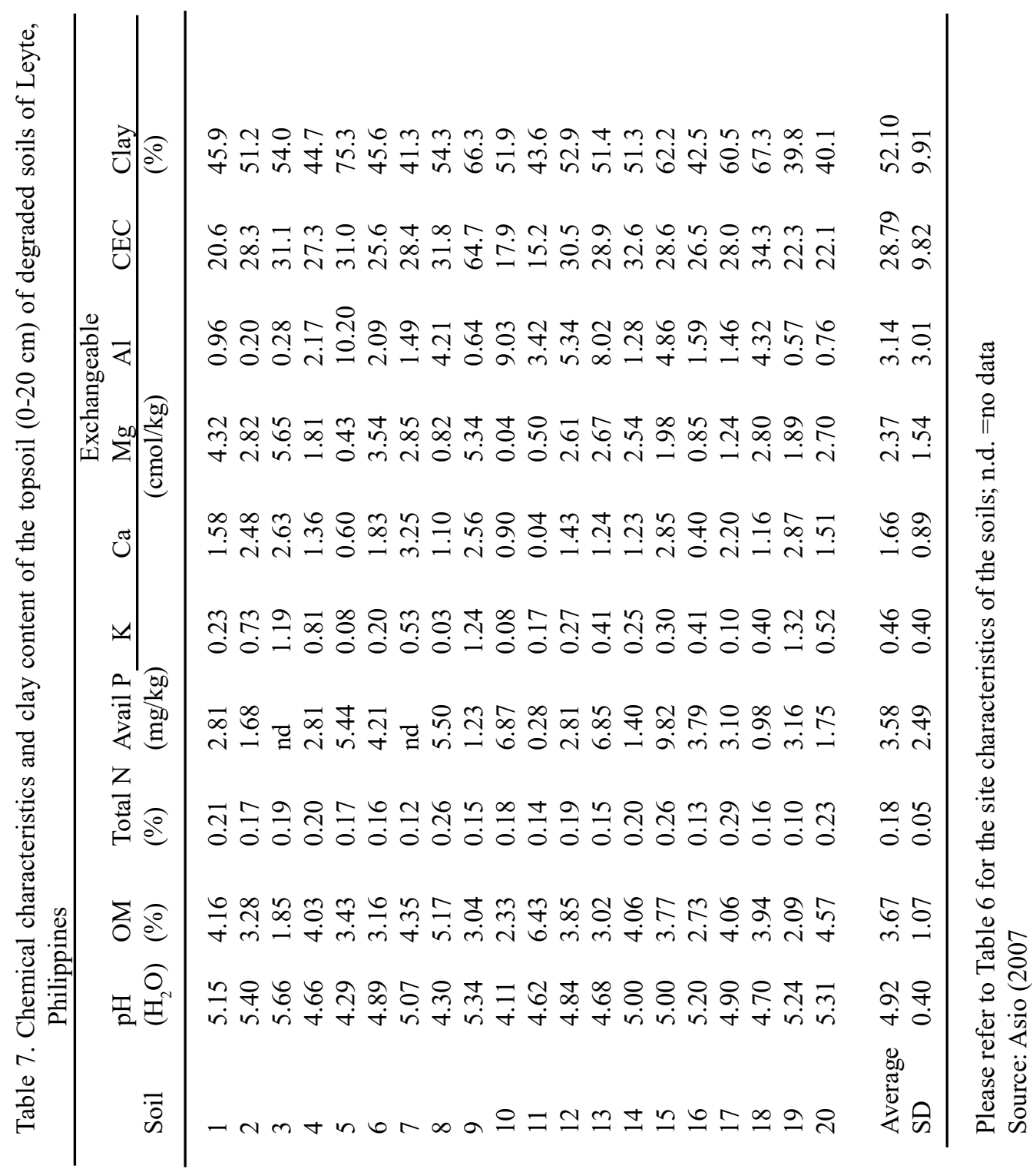


suggesting that $\mathrm{K}$ is not a major problem in the degraded soils. This is because $\mathrm{K}$ is supplied by primary minerals like feldspars that are abundant in volcanic rocks. The same can be said of the exchangeable $\mathrm{Ca}$ and $\mathrm{Mg}$ which are also above the critical values of 0.4 and $0.5 \mathrm{cmol} \mathrm{kg}^{-1}$. Cation exchange capacity of the soils which reflect the ability of the soil to hold nutrients, ranges from moderate to high which is partly due to their high clay contents. Most of the soils have high levels of exchangeable Al implying Al toxicity as a potential constraint to crop growth in the degraded soils. Steiner (1996) reported that degraded soils are generally characterized by depletion of nutrient reserves or soil impoverishment, depletion of organic matter and associated deterioration of soil structure, soil acidification combined with aluminum toxicity. The soil problems could vary depending on the original characteristic of the soil before degradation, the causes of soil degradation, and the soil management applied by the farmers (Steiner, 1996). Jahn (1999) noted several chemical limitations to plant growth in degraded upland tropical soils like low cation exchange capacity, low base saturation, and high $\mathrm{P}$ retention. $\mathrm{He}$ added that due to severe chemical limitations, proper management of nutrients is the main challenge for land use in these soils.

Field observations revealed that degraded soils possess physical constraints which affect soil use and management like sticky and plastic characteristics when the soil is wet but compact when it is dry. Most of the soils also show moderate to severe erosion. In general, the degraded upland soils can be identified in the field based on the vegetation cover and soil surface morphology. The common plant species in the degraded upland soils are: Imperata cylindrical (L) Beauv., Saccharum spontaneum L., Paspalum conjugatum Bergius, Axonopus compressus (Sw.) P. Beauv., Cyrtococcum accrescens(Trin.) Stapf, Melastoma affine D. Don., and the native Psidium guajava L. In terms of soil surface morphology, degraded upland soils have red topsoils, abundance of erosion rills and gullies, thin A horizons, and rock fragments (Asio, 1997 and 2007). In terms of soil degradation processes that occurred in the soils, there is clear evidence for soil erosion, loss of nutrients and organic matter as well as acidification. 


\section{Management of degraded soils}

Degraded soils are a major problem for agriculture because of the various chemical and physical constraints they possess. Because the properties of degraded soils widely vary, soil management strategies are site specific. This requires that every degraded soil has to be evaluated in terms of its properties and constraints. Snelder (2001) who worked on the degraded grasslands of Northeast Luzon, observed that the variable soil conditions and topography are inadequately considered in regional attempts to develop and rehabilitate these lands.

Comia (1999) reported on the various effective indigenous (e.g. fallow-till system) and introduced (e.g. alley cropping) soil conservation systems that are practiced by farmers in various parts of the country. $\mathrm{He}$ suggested that these practices can be applied to other areas but noted that the main challenge is to develop systems that minimize labor, or which incorporate hedgerow species that provide income to farmers. He recommended that conservation farming advocates must start with what the farmers have.

Reforestation is the traditional and most widely promoted approach to rehabilitating degraded lands. Reforestation projects in the past have not been very successful due to, among other factors, the use of exotic tree species which are difficult to establish in infertile degraded upland soils. It is now widely known that the use of exotic species in reforestation projects does not improve biodiversity and site quality (Asio \& Bande, 2005). An alternative approach is the use of indigenous tree species particularly the hardwood Dipterocarp species that are available locally in combination with some food crops. Such approach has been proven effective in the restoration of degraded lands in various sites in Leyte (Asio \& Milan, 2002).

In recent years, Jatropha (Jatropha curcas L.) has become popular in the Philippines and many other countries in Asia and Africa since it can be used as source of biodiesel. The Philippine Renewable Energy Act of 2008 promotes the planting of Jatropha in degraded lands since the plant is widely known to grow in stressed soil environments. Results of our experiment at Visayas State University (Lasquites et al., 2008) 
revealed that although Jatropha can indeed thrive under degraded soil conditions, it needs sufficient nutrient supply to grow well and produce the oil-containing seeds. In addition, without soil amendments, Jatropha did not grow well in severely degraded calcareous and acidic soils (Fig. 3 ). However, addition of manures enabled it to grow well in both types of degraded soil.

The use of vermicompost as soil enhancer for degraded soils is also being promoted by some government agencies. The use of vermicompost is not something new. Like any organic fertilizer, adequate amount of vermicompost is expected to improve the fertility status of degraded soils especially those low in humus content. However, the use of non-native (exotic) earthworm species may cause serious ecological problems in the future. Thus, it is necessary that studies on the long-term ecological impact of vermicomposting should be done.

Cramb (2001) observed that one cause for the failure of soil management technologies in the Philippines is the introduction of inappropriate technologies to farmers in degraded lands. According to him, many crop production technologies developed for the marginal upland areas have not been adopted by farmers or have failed to increase crop yields in these stressed environments. One major contributing factor to this problem is the fact that degraded upland soils in the Philippines are still poorly understood until now since very little data are available on their characteristics (Asio, 1997; Asio et al., 1999). In fact, the lack of information about degraded upland soils have also contributed to the failure of the major government effort at massive forest rehabilitation in the past (Alcala, 1997).

\section{CONCLUSIONS}

Soil degradation is a major ecological problem in the Philippines. Degraded lands are widely seen as a major contributor to the frequent occurrence of disastrous floods in certain provinces and to the poor economic conditions of upland farmers. Appropriate and sustainable soil management strategies are needed which in turn require detailed knowledge of the properties and limitations of the degraded soils which 
until now are limited. There is the danger that the intensive use of the degraded lands for biodiesel production without the appropriate soil management would cause further soil deterioration and thus aggravate the ecological problems that are now occurring. The review has confirmed that soil erosion is the most widespread and studied type of soil degradation processes in the Philippines but estimates of the rate of soil loss are greatly variable due to the different methodologies used and the varying environmental factors. Very few studies have been done on the other types of soil degradation such as the chemical and physical soil degradation.

\section{REFERENCES}

ADDISCOTT, TM. 1995. Entropy and sustainability. European Journal of Soil Science 46: $161-168$.

ALCALA, A.C. 1997. Keynote address. Proceedings of International Conference on Reforestation with Philippine Species. (date?) ViSCA-GTZ Ecology Project, Baybay, Leyte, Philippines.

ASIO, V.B. 1996. Characteristics, weathering, formation, and degradation of soils from volcanic rocks in Leyte, Philippines. Hohenheimer Bodenkundliche Hefte, Vol. 33, Stuttgart, Germany.

ASIO, V.B. 1997. A review of upland agriculture, population pressure, and environmental degradation in the Philippines. Annals of Tropical Research 19: 1-18.

ASIO, V.B. 2007. Characteristics, fertility status, and management of degraded upland soils in Leyte. In: PARRFI Professorial Chair Lectures 1992-2006, Philippine Agricultural Resources Resarch Foundation Incorporated (PARRFI). Laguna.

ASIO, V.B. and M. J. M. BANDE.2005. Innovative community-led sustainable forest resource conservation and management in Baybay, Leyte, Philippines. In: Velasquez J, Yashiro M, Ono I. (eds) Innovative communities: people-centered approaches to environmental management in the Asia-Pacific Region. United Nations University Press, Tokyo.Pp. 204-224.

ASIO, V.B. and P. P. MILAN. 2002. Improvement of soil quality in degraded lands through rainforestation farming. Paper presented during the International Symposium on Sustaining Food Security and Managing Natural Resources in Southeast Asia, January 8-11, 2002, Chiang Mai, Thailand. 
ASIO, V.B., R. JAHN, and K. STAHR. 1999. Changes in the properties of a volcanic soil in Leyte due to conversion of forest to other land uses. Philippine Journal of Science 128: 1-13.

ASIO, V.B., R. JAHN, K. STAHR, and J. MARGRAF. 1998. Soils of the tropical forests of Leyte, Philippines: II. Impact of different land uses on status of organic matter and nutrient availability. In: Schulte A, Ruhiyat D (eds) Soils of Tropical Forest Ecosystems. Springer-Verlag, Berlin.Pp.37-44.

ATIENZA, R.N., J. HAPAL, and E. MOGA. 2008. Legislative and institutional aspects of soil and water conservation: the Philippine experience. 15th ISCO Conference, Budapest.

BLOOM, P.R. 2000. Soil pH and pH buffering. In: Sumner ME (ed.) Handbook of Soil Science. Pp. G3-G25. CRC Press, Boca Raton.

BLUM, W.E.H. 1998. Basic concepts: degradation, resilience, and rehabilitation. In: Lal R, Blum WEH (eds) Methods for Assessment of Soil Degradation, Advances in Soil Science. CRC Press, Boca Raton. Pp. 1-16.

BLUM, W.E.H. 2007. Bodenkunde in Stichworten (6. Auflage) Borntraeger, Stuttgart.

BSWM .1992. Philippine Land and Soil Management Atlas for Eastern Visayas. Bureau of Soil and Water Management (BSWM), Department of Agriculture, Quezon City.

COMIA, R.A. 1999. Soil and nutrient conservation oriented practices in the Philippines. FFTC Bulletin, Taiwan.

CRAMB, R.A. (ed). 2001. Soil conservation technologies for smallholder farming systems in the Philippine uplands: a socioeconomic evaluation. ACIAR, Australia.

CRAMB, R.A., J. N. M. GARCIA, R.V. GERRITS, and G. C.SAGUIGUIT.2000. Conservation farming projects in the Philippine uplands: rhetoric and reality. World Development 28: 911-927.

DAVID, C.P. 2002. Heavy metal concentrations in marine sediments impacted by a mine-tailings spill, Marinduque Island, Philippines. Environmental Geology 42: 955-965.

DAVID, W.P. 1984. Environmental effects of watershed modifications. Philippine Institute for Development Studies. Working Paper 84-07, Manila.

DAVID, W.P. 1988. Soil and water conservation planning: policy issues and recommendations. Journal of Philippine Development XV: 47-84. 
EDRALIN, D.E.A. 2008. Copper, lead, nitrogen, and phosphorus levels in soils and plants in the abandoned Bagacay Mine in Samar, Philippines (MSc thesis). Institute of Tropical Ecology. Visayas State University, Baybay, Leyte, Philippines.

EVANGELISTA, P.P. 1993. Land use on uplands. Paper presented during the 3rd International Forum on Soil Taxonomy and Sustainable Land Management. 1728 May 1993. BSWM, Diliman, Quezon City, Philippines.

FAO (1998) Soil resource depreciation and deforestation: Philippine case study in resource accounting. Rome.

GARRITY, D.P., D.M. KUMMER, and E.S. GUIANG. 1993. The Philippines. In: Committee on Sustainable Agriculture and the Environment in the Humid Tropics. Board on Agriculture and Board on Science and Technology for International Development and National Research Council (eds) Sustainable Agriculture and the Environment in the Humid Tropics. National Academy Press, Washington.

JAHN, R. 1999. Management of soils in the humid tropics. Proceeding of the International Conference on Applied Tropical Ecology. 8-10 September 1998. Leyte State University, Baybay, Leyte.

LAL, R. 1984. Soil erosion from tropical arable lands and its control. Advances in Agronomy 37: 183-248.

LAL, R. 1998. Soil quality and sustainability. In: Lal R, Blum WEH (eds) Methods for Assessment of Soil Degradation Advances in Soil Science. CRC Press, Boca Raton.Pp. 17-30.

LAL, R. 2001. Soil degradation by erosion. Land Degradation and Development 12: 519-539.

LANDON, J.R.(ed) 1991. Booker tropical soil manual. Longman Scientific and Technical, England.

LANTICAN, A., L. C. GUERRA, and S. I. BHUIYAN.2003. Impacts of soil erosion in the upper Manupali watershed on irrigated lowlands in the Philippines. Paddy water Environment 1, 19-26.

LASQUITES, J.J.S., C. M. QUINONES, A. B. TULIN, V. B. ASIO, and R. C. GUARTE. 2008. Growth performance of Jatropha plants and its effect on some chemical properties as influenced by organic and inorganic fertilizer application under acidic and calcareous soil conditions. Best Poster Paper, National Scientific Meeting of the Philippine Society of Soil Science and Technology, 27-29 May 2008, Bohol, Philippines. 
MINES AND GEOSCIENCES BUREAU (MGB) 2004. The Philippine Mineral Sector. DENR, Quezon City, Philippines.

MINES AND GEOSCIENCES BUREAU-MINING ENVIRONMENT AND SAFETY DIVISION (MGB-MESD). 2006. Environmental assessment of abandoned Bagacay mine relative to the proposed interim remediation measures of the World Bank supported project. DENR, Quezon City, Philippines

NATIONAL ACTION PLAN (NAP).2004. The Philippine National Action Plan to combat desertification, land degradation, drought, and poverty for 2004-2010. Department of Agriculture, Department of Environment and Natural Resources, Department of Science and Technology, and Department of Agrarian Reform, Manila, Philippines.

NAVARRETE, I.A. and K. TSUTSUKI. 2008. Land-use impact on soil carbon, nitrogen, neutral sugar composition and related chemical properties in a degraded Ultisol derived from volcanic materials in Leyte, Philippines. Soil Science of Plant Nutrition 54: 321-331.

NAVARRETE, I.A., K. TSUTSUKI, V. B. ASIO, and R. KONDO.2008. Genesis of soils across a late Quaternary volcanic landscape in the humid tropical island of Leyte, Philippines. Australian Journal of Soil Research 46: 403-414.

NAVARRETE, I.A., V. B. ASIO, R. JAHN, and K.TSUTSUKI .2007. Characteristics and genesis of two highly weathered soils in Samar, Philippines. Australian Journal of Soil Research 45: 153-163.

NAVARRETE, I.A., V. B. ASIO, E. BALBARINO, and A. B. TULIN. 2000. The physicochemical properties of rhizosphere soil grown to vetiver in a degraded upland. Grassland Society of the Philippine Journal 4: 29-34.

OLDEMAN, L.R. 1994. Global extent of soil degradation. In: Oldeman LR (ed) Soil resilience and sustainable use. CAB International, UK.Pp. 99-118.

ONA, L.F., A. M. P. ALBERTO, J. A. PRUDENTE, and G. C. SIGUA.2006. Levels of lead in urban soils from selected cities in a central region of the Philippines. Environmental Science and Pollution Research 13: 177-183.

PANINGBATAN, E.P., C. A. CIESOLKA, K. J. COUGHLAN, and C. W. ROSE. 1995. Alley cropping for managing soil erosion of hilly lands in the Philippines. Soil Technology 8: 193-204.

PCARRD. 1992. Management and rehabilitation of degraded hillylands. Terminal report of the PCARRD/IBSRAM Project, PCARRD, Los Banos, Laguna. 
PCARRD. 2009. Philippine S\&T agenda on climate change 2010-2016. Agriculture, Forestry \& Natural Resources Section. PCARRD, Laguna. 113 pp.

PHILRICE. 2001. Management of salt-affected soils for rice production. Rice Technology Bulletin No. 40, Philippine Rice Research Institute, Munoz, Nueva Ecija.

PONNAMPERUMA, F.N. and A. K. BANDYOPADHYA.1980. Soil salinity as a constraint on food production in the humid tropics. In: Priorities for Alleviating Soil-Related Constraints to Food Production in the Tropics. . IRRI, Los Banos, Laguna, Philippines. Pp. 203-216

POUDEL, D.D., D. J. MIDMORE, and L. T. WEST. 1999. Erosion and productivity of vegetable systems on sloping volcanic ash-derived Philippine soils. Soil Science Society of American Journal 63: 1366-1376.

POUDEL, D.D., D. J. MIDMORE, and L. T. WEST. 2000. Farmer participatory research to minimize soil erosion on steepland vegetable systems in the Philippines. Agriculture, Ecosystems and Environment 79: 113-127.

PRESBITERO, A.L. 2003. Soil erosion studies on steep slopes of humid-tropic Philippines ( $\mathrm{PhD}$ dissertation). Griffith University, Australia.

PRESBITERO, A.L., M. C. ESCALANTE, C. W. ROSE, K. J. COUGHLAN, and C. A. CIESIOLKA. 1995. Erodability evaluation and the effect of land management practices on soil erosion from steep slopes in Leyte, the Philippines. Soil Technology 8, 205-213.

SANCHEZ, P.A. 1976. Properties and management of soils in the tropics. Wiley and Sons, New York.

SCHERR, S.J. 1999. Soil degradation: a threat to developing country food security by 2020?. 2020 Brief No. 58, IFRI, Washington, D.C.

SIEBERT, S.F. 1987. Land use intensification in tropical uplands: effects on vegetation, soil fertility and erosion. Forest Ecology and Management 21: 37-56.

SMECK, N.E., E. C. A. RUNGE, and E. E. MACKINTOSH.1983. Dynamics and genetic modeling of soil systems. In: Wilding L.P. et al. (eds) Pedogenesis and Soil Taxonomy. I. Concepts and Interactions. Elsevier, Amsterdam.Pp. 51-81.

SNELDER, D.J. 2001. Soil properties od Imperata grasslands and prospects for treebased farming systems in Northeast Luzon, The Philippines. Agroforestry Systems 52: $27-40$.

STEINER, K.G. 1996. Causes of soil degradation and development approaches to sustainable soil management. Margraf Verlag, Weikersheim. 
STREMME, H. 1930. Degradierte Böden. In: Blanck E (ed) Handbuch der Bodenlehre. Dritter Band. Verlag von Julius Springer, Berlin.Pp. 505-521.

THE WORLD BANK. 1989. Philippine environment and natural resource management study. A World bank country report. The World Bank, Washington, D.C.

UNEP.1992. World Atlas of Desertification. Edward Arnold, London.

VAN LYNDEN, G.W.J., and L. R. OLDEMAN. 1997. The assessment of the status of human-induced soil degradation in South and Southeast Asia. ISRIC, Wageningen.

VERBURG, P.H., and A. VELDKAMP. 2004. Projecting land use transitions at forest fringes in the Philippines at two spatial scales. Landscape Ecology 19: 77-98. 